\title{
A RECORD OF PARASITISM OF TROPICAL GRASS WEBWORM IN NEW ZEALAND
}

\author{
D.L. HACKELL and S. HARDWICK \\ AgResearch, Ruakura Research Centre, Private Bag 3123, Hamilton \\ Corresponding author: deborah.hackell@agresearch.co.nz
}

Breeding populations of tropical grass webworm (Herpetogramma licarsisalis) in New Zealand were first observed in Northland during the summer of 1998/1999 and were associated with considerable damage to kikuyu pastures. An investigation into naturally occurring parasitoids that could assist in the control of tropical grass webworm on the Aupouri Peninsula, Northland, New Zealand, was undertaken between March and May 2004. During this monitoring period two species of parasitoids were reared from tropical grass webworm larvae collected from four sites. These were identified as Meteorus pulchricornis (Wesmael) (Hymenoptera: Braconidae) and a Pales sp., akin to $P$. tecta Hutton (Diptera: Tachinidae). Prior to the investigation only two hymenopteran parasitoids, Lissopimpla excelsa (Costa) (Hymenoptera: Ichneumonidae) and a campoplegine ichneumonid, had been observed in association with New Zealand populations of tropical grass webworm. This is the first confirmed record of M. pulchricornis and Pales sp. parasitising tropical grass webworm in New Zealand.

\section{POTENTIAL OF ETHYL (2E,4Z)-2,4-DECADIENOATE FOR MONITORING CODLING MOTH IN NEW ZEALAND}

\author{
V.J. MITCHELL, L.M. MANNING, N. FLETCHER, D.M. SUCKLING \\ and A.M. EL-SAYED
}

HortResearch, P.O. Box 51, Lincoln, New Zealand

Corresponding author: VMitchell@hortresearch.co.nz.

The amount of synthetic codling moth (Cydia pomonella (L.)) sex pheromone, $E, E-8,10$-dodecadien-1-ol, (0.01-10.0 mg) used as a bait in traps significantly affected the mean number of male moths captured in apple orchards. No dose response in catch of males was seen in traps baited with different amounts of pear-derived kairomone, ethyl (2E,4Z)-2,4-decadienoate $(0.01-10.0 \mathrm{mg})$. The number of females caught was significantly affected by the amount of pear-derived kairomone used to bait traps, with the highest catch at 1 and $10 \mathrm{mg}$. The attractiveness of sex pheromone was not enhanced by the addition of the kairomone, either when used in the same bait or as separate bait. The potential usefulness of kairomone-baited traps in the integrated management of C. pomonella in New Zealand apple orchards is discussed. 